\title{
Improving pineapple micropropagation protocol through explant size and medium composition manipulation
}

Lirio Luiz Dal Vesco a, Adelar de Almeida Pinto ${ }^{a}$, Gilmar Roberto Zaffari ${ }^{b}$, Rubens Onofre Nodaria ${ }^{a}$ Maurício Sedrez dos Reis ${ }^{a}$, Miguel Pedro Guerra ${ }^{a \star}$

a Universidade Federal de Santa Catarina, CCA, Departamento de Fitotecnia, Florianópolis,

SC, Cx. Postal 476 - CEP 88034-001, Brazil

E-mail: mpguerra@cca.ufsc.br Fax: (048) 331-5400

b Estação Experimental de Itajal (EPAGRI),

C.P. 277 , Itajaí,

SC. 88.301-970, Brazil
* Correspondence and reprints

Received 17 February 2000 Accepted 15 December 2000

Fruits, 2001, vol. 56, p. 143-154 (C) 2001 Cirad/EDP Sciences All rights reserved

Resumen Español, p. 154

\section{Improving pineapple micropropagation protocol through explant size and medium composition manipulation.}

Abstract - Introduction. Although several pineapple micropropagation protocols have already been published, significant improvement could be achieved if the stages of the in vitro culture were better defined. Our work concerned several experiments aiming at the mass production of high quality plantlets. Materials and methods. Axillary buds were inoculated on an MS liquid culture medium added with NAA $(2 \mu \mathrm{M})$ and BAP $(4 \mu \mathrm{M})$. Regenerated shoots, divided into three classes of different sizes, were then used in further experiments. First, these shoots were inoculated in flasks containing the same MS culture medium with or without growth regulators. Then, four basic media, containing different salts and free from growth regulators were tested. In a third assay, the MS culture medium was compared with a half-diluted MS culture medium for studying the plantlet elongation and rooting stage. Results. In the MS culture medium supplemented with NAA and BAP, the highest multiplication rate (13.5 shoots) was obtained with the smallest shoots inoculated, while in the MS culture medium free of growth regulators, the highest plantlets $(7.7 \mathrm{~cm})$ were the result of the highest shoots inoculated and showed no vitrification. The normal MS culture medium, in comparison with the half-diluted one and the three other salt formulations, revealed a significant increase in the plantlet elongation and best general features. For acclimatization, the highest values of the survival rate $(93.8 \%)$ and fresh and dry weights were obtained with the transference of higher than $7.0 \mathrm{~cm}$ in vitro plantlets. Conclusion. Using the protocol described in this work, it is possible to obtain 1 million in vitro plantlets after 9 months from a single bud, with a 45 day subculture interval and an average multiplication rate of 10 shoots per bud.

Brazil / Ananas comosus / plant propagation / micropropagation / in vitro experimentation / culture media / transplanting / plant establishment

\section{Amélioration du protocole de micropropagation de l'ananas par modification de la taille de l'explant et de la composition du milieu de culture.}

Résumé - Introduction. Bien que plusieurs protocoles de micropropagation d'ananas aient déjà été publiés, une amélioration significative pourrait être réalisée si les étapes de la culture in vitro étaient mieux définies. Nos travaux ont porté sur plusieurs expérimentations visant la fabrication en série de plantules de haute qualité. Matériel et méthodes. Des bourgeons axillaires ont été inoculés sur un milieu de culture MS liquide additionné d'ANA $(2 \mu \mathrm{M})$ et de BAP $(4 \mu \mathrm{M})$. Les pousses régénérées, réparties en trois classes de tailles différentes, ont alors été utilisées pour d'autres expérimentations. Elles ont d'abord été mises en culture dans des flacons contenant le même milieu de culture MS avec ou sans régulateurs de croissance. Puis quatre milieux de base, contenant des sels différents et exempts de régulateurs de croissance, ont été testés. Dans une troisième analyse, le milieu de culture MS a été comparé à un milieu MS dilué de moitié pour étudier l'étape d'élongation et d'enracinement des plantules. Résultats. Sur le milieu de culture MS, complété d'ANA et de BAP, le taux de multiplication le plus élevé (13,5 pousses) a été obtenu avec les plus petites pousses mises en culture, alors que, sur le milieu de culture MS sans régulateurs de croissance, les plantules les plus hautes $(7,7 \mathrm{~cm})$ ont été issues des plus hautes pousses mises en culture ; elles n'ont montré aucune vitrification. Le milieu de culture MS normal, comparé à celui dilué de moitié et aux trois autres formulations de sel, a provoqué une augmentation significative de l'élongation des plantules et un meilleur état général de celles-ci. Pour l'acclimatation, les taux de survie les plus forts (93,8 \%) et les poids frais et secs les plus élevés ont été obtenus à partir du transfert des vitroplants mesurant plus de $7,0 \mathrm{~cm}$. Conclusion. En utilisant le protocole décrit dans ce travail, il est possible d'obtenir 1 million de plantules en 9 mois, à partir d'un seul bourgeon, avec un interval de $45 \mathrm{j}$ entre repiquages successifs et un taux de multiplication de 10 pousses par bourgeon.

Brésil / Ananas comosus / multiplication des plantes / micropropagation / expérimentation in vitro / milieu de culture / repiquage / établissement de la plante 


\section{Introduction}

The pineapple (Ananas comosus (L.) Merr.) is a very important fruit crop in Brazil. Since the late 70s, the cultivated area with this species has decreased due to the occurrence of fusariosis, a very devastating disease. The fusariosis, or gomosis, (Fusarium subglutinans WR) is disseminated through the cutting type slips and suckers, and causes losses of more than $30 \%$ of the Brazilian production. The efficient ways to control this disease are the use of plantlets free of the pathogen or resistant cultivars [1-3]. Thus, micropropagation techniques are valuable tools for mass clonal propagation of superior clones or varieties. A good micropropagation protocol should provide plantlets with a high quality and multiplication rate at a low cost.

The first pineapple micropropagation protocol was described in 1960 [4]. Afterwards, a protocol for multiple proliferation was established from lateral buds [5]. Several other explant sources have been tested successfully in several regenerative protocols [6-14]. An alternate pineapple micropropagation protocol with etiolated shoots was established resulting in high multiplication rates [15].

Other protocols based on organogenesis were described $[5,16,17]$ using different explants such as lateral buds, crown apical dome and ovules. Besides the explant source, variations of the culture medium composition and environment such as $\mathrm{CO}_{2}$ enrichment and light intensity associated with the sucrose content can affect the micropropagation performance [18].

The general protocols of direct organogenesis in pineapple are based on the following stages: 1 ) selection and preparation of an explant donor plant; 2) establishment of aseptic culture and induction; 3) multiplication; 4) rooting; 5) establishment of plantlets in soil. In the present work, we are proposing the exclusion of some stages and the inclusion of new stages of development, in relation to the micropropagation stages previously suggested [19-21].
A micropropagation protocol superior to the previous one should be enhanced to be used widely. Thus, the present work was carried out to improve the previous pineapple micropropagation protocol [14] through manipulating both explant size and medium composition, as well as acclimation substrates and plantlet size, aiming for the mass clonal micropropagation of plantlets free of fusariosis.

\section{Materials and methods}

\subsection{Explant donor plant, extraction and explant disinfestation}

Pineapple plants from cv. Pérola, a welladapted variety of the coast-producing region of the State of Santa Catarina, Brazil, were selected in the field and cultivated in the greenhouse prior to an explant excision. The axillary bud explants were excised from the central region of the donor plant stem, and subjected to a disinfestation process as previously described [14].

\subsection{Bud isolation and shoot induction}

In an aseptic chamber, the buds were inoculated in test tubes $(22 \mathrm{~mm} \times 150 \mathrm{~mm})$ over paper filter bridges on a liquid basal culture Murashige and Skoog (MS) medium [22] supplemented with sucrose (3\%), naphthaleneacetic acid NAA $(2 \mu \mathrm{M})$ and 6-benzylaminopurine (BAP) $(4 \mu \mathrm{M})$. The $\mathrm{pH}$ was adjusted to 5.8 before autoclaving. Three weeks after inoculation, the cultures were initially transferred to $200 \mathrm{~mL}$ glass flasks, containing $10 \mathrm{~mL}$ of a culture medium, then subcultured into $500 \mathrm{~mL}$ glass flasks containing $30 \mathrm{~mL}$ of the same liquid medium. At every stage, the cultures were kept in the growth room at a temperature of $(27 \pm 2){ }^{\circ} \mathrm{C}$, $16 \mathrm{~h}$ photoperiod, $60 \%$ relative humidity and $37 \mu \mathrm{mol} \times \mathrm{m}^{-2} \times \mathrm{s}^{-1}$ light intensity.

\subsection{Multiplication}

A first experiment was established to compare the effect of MS liquid medium supplemented by or devoid of NAA and BAP 
on the multiplication rate and plantlet quality. The objective of this assay was to optimize this multiplication stage, especially to identify inductive factors of vitrification; to reduce the residual effects of the growth regulator, and to prepare plantlets for acclimatization.

The experimental design was a $(2 \times 3)$ cross classification model with two factors. Factor A was composed of a liquid MS culture medium alone or with NAA $(2 \mu \mathrm{M})$ and BAP $(4 \mu \mathrm{M})$. Factor B was composed of the shoot heights: each level of factor A was combined with shoots of three classes of height: $\mathrm{C} 1=(1.1$ to 2.0$) \mathrm{cm}$; $\mathrm{C} 2=(2.1$ to $3.0) \mathrm{cm} ; \mathrm{C} 3=(3.1$ to 4.0$) \mathrm{cm}$, obtained from successive subcultures in the induction medium. Each experimental unit constituted eight plants, with three replicates, arranged in a completely randomized design. Data on the number of shoots and roots, shoot height and shoot diameter were collected 5 weeks after the inoculation.

\subsection{Elongation and rooting}

A second experiment was done concerning the identification of the best basal salt culture medium composition, free of growth regulator, to promote the plantlet growth and rooting.

The experimental design was a $(4 \times 3)$ cross classification model with two factors. Factor A was composed of four basal salt media formulations: LPm medium [23], MS medium [22], N6 medium [24] and KC medium [25]. Factor B was composed of the shoot heights: each basal medium was combined with the three different classes of shoot heights (factor B), C1, C2, and C3, described previously. Explants were originated from the multiplication stage.

A third experiment had the objective of providing a maximum increment of shoot growth, prior to the acclimatization stage. The design was a $(2 \times 3)$ cross classification model with two factors. Factor A constituted the basal MS and $1 / 2 \mathrm{MS}$ culture media free of growth regulators. These two treatments were combined with shoots of the three different classes of height (factor B) previously described.
Each experimental unit of these last two experiments constituted eight plants, with four replicates, arranged in a completely randomized design. Data on shoot and root number, shoot height and diameter were collected 5 weeks after the inoculation.

\subsection{Acclimatization}

Plantlets originated from the elongation and rooting stage were classified according to their height and transplanted into containers. The soil used in the containers was a mixture of organic thermophilic composite not autoclaved and autoclaved sand, at the ratio of $5: 1(\mathrm{v}: \mathrm{v})$. The plants were kept in a greenhouse for 4 weeks. The experimental design of this fourth experiment was a complete randomized block, the treatments being the three classes of plantlet height: C4 (3.1 to 5.0) cm, C5: (5.1 to 7.0) $\mathrm{cm}$, and C6 (7.1 to 9.0$) \mathrm{cm}$. Each experimental unit constituted 16 plantlets, replicated three times.

In a fifth experiment, plantlets higher than $6.0 \mathrm{~cm}$, originated from the elongation and rooting stage, were submitted to different substrate compositions and sterilization processes under a $(2 \times 3)$ cross classification model design. In factor A, two substrates were included: S1 = mixture of sand and thermophilic organic composite at the ratio of 5:1 (v:v) and S2 = sand. Both S1 and S2 were combined with three processes of substrate autoclaving (factor B): a) two autoclavings of 30 min with a $24 \mathrm{~h}$ interval, at $121^{\circ} \mathrm{C}$ and $1 \mathrm{~atm}$; b) one autoclaving under the same conditions; c) not autoclaved control treatment. Each experimental unit, repeated four times, arranged in a completely randomized design, was constituted of eight plants. The conditions for the plantlet growth were similar to the previous experiment. Data on the height and fresh and dry weight of plantlets were collected in the thirteenth week after the transference.

\subsection{Statistical analysis}

Both primary and transformed data of in vitro and ex vitro experiments were submitted to the analysis of variance and to the 
Student-Newman-Keuls (SNK) mean separation test [26, 27].

\section{Results}

\subsection{Bud induction}

The basal MS liquid culture medium supplemented with NAA $(2 \mu \mathrm{M})$ and BAP $(4 \mu \mathrm{M})$ was revealed to be an effective method for pineapple in vitro initiation. The successive subcultures enhanced the multiple bud proliferation. The induction of multiple buds occurred after 3 weeks in culture.

\subsection{Shoot multiplication and elongation}

Shoots of the $\mathrm{C} 1$ and $\mathrm{C} 2$ classes inoculated in the basal medium MS plus NAA $(2 \mu \mathrm{M})$

\section{Figure 1.}

Shoot height [data transformed using $\log (x+2)$, significant at $P<0.05, \mathrm{CV}=2.8 \%)] /$ and number of shoots (significant at $P<0.01, \mathrm{CV}=19.6 \%$ ) of pineapple in response to two different culture media, 5 weeks after the inoculation of plantlets originating from three different height classes (mean of three replicates, Student-Newman-Keuls test).

\section{Figure 2.}

Shoot diameter (significant at $P<0.01, \mathrm{CV}=11.2 \%)$ and number of roots (significant at $P<0.01, \mathrm{CV}=23.5 \%$ ) of pineapple in response to the two different culture medium, 5 weeks after the plantlet inoculation (mean of three replicates, Student-Newman-Keuls test).
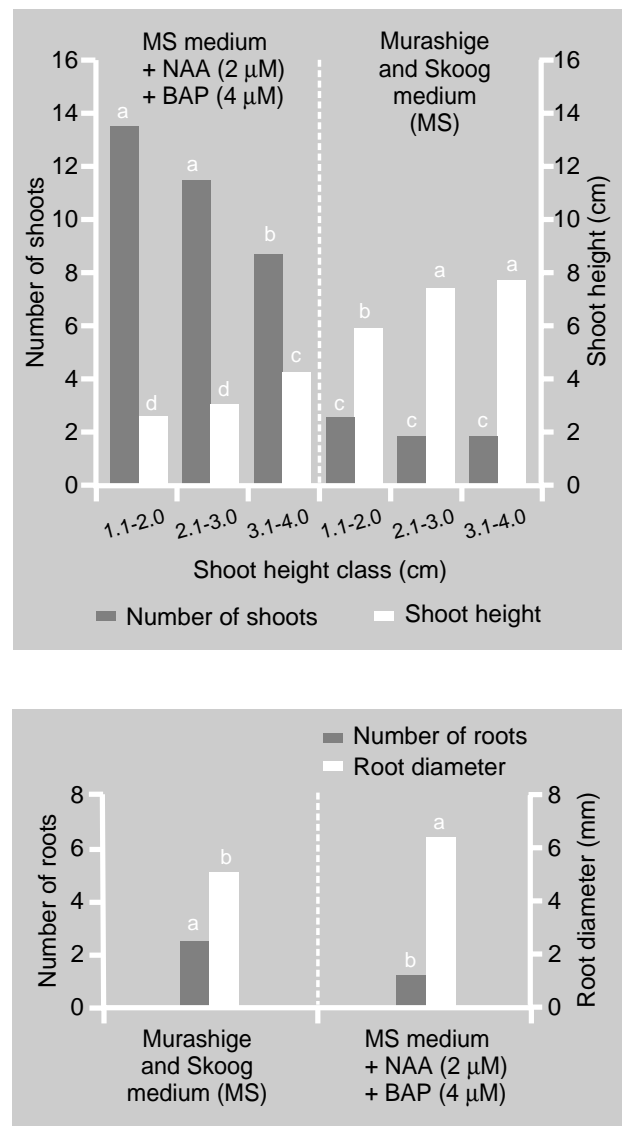

and BAP $(4 \mu \mathrm{M})$ provided the highest multiplication rate, reaching 13.5 and 11.5 shoots, respectively, in 5 weeks (figure 1). These values were significant at $\mathrm{P}<0.05$ by SNK test compared to plantlets from the class $\mathrm{C} 3$ cultivated without growth regulator. However, when shoots were inoculated in culture medium free of NAA and BAP, higher values for shoot height were observed for the $\mathrm{C} 2$ and $\mathrm{C} 3$ classes (figure 1). In addition, the results revealed an inverse relationship between the height and the shoot number, which was affected by the culture medium composition. Nevertheless, while the addition of NAA and BAP to basal medium resulted in higher shoot diameter, the highest number of roots was observed in basal medium free of growth regulators (figure 2).

The frequency of shoots with vitrification was associated with the culture medium. While $10 \%$ of the shoots showed vitrification in the supplemented medium, the vitrification was observed in $1 \%$ of the shoots in the culture medium free of growth regulators.

The different salt media formulations significantly $(P<0.05)$ affected the plantlet height and root numbers (table I). The ANOVA also disclosed values with statistical differences $(P<0.01)$ between explant size classes, for the development of plantlet parameters such as plantlet height and diameter. Significant interaction $(P<0.01)$ between the basal salt formulation and the explant size class also influenced the number of roots per plantlet (tableI). Five weeks after inoculation, MS basal medium revealed a plantlet height average of $7.9 \mathrm{~cm}$ and 1.3 shoots per explant, values differing by the SNK $(\mathrm{P}<0.05)$ test from those observed in other salt formulations. However, the average of 7.0 roots per plantlet observed in the LPm medium was the highest among the other salt formulations. It is also shown (table I) that the lowest average plantlet height and root number resulted from inoculation of the $\mathrm{C} 1$ class of shoots in the N6 basal medium. When the explant size classes were analyzed, class $\mathrm{C} 3$ showed higher plantlet height $(6.6 \mathrm{~cm})$ and diameter $(6.2 \mathrm{~mm})$, in comparison with classes $\mathrm{C} 2$ and $\mathrm{C} 1$. 


\section{Table I.}

Characteristics of pineapple (cv. Perola) plantlets after 5 weeks of in vitro cultivation on media with different salt formulations (means of four replicates).

\begin{tabular}{|c|c|c|c|c|c|c|}
\hline \multirow{2}{*}{$\begin{array}{l}\text { Class of shoot } \\
\text { height }(\mathrm{cm})\end{array}$} & \multicolumn{5}{|c|}{ Culture medium } & \multirow{2}{*}{$\begin{array}{c}\text { Coefficient } \\
\text { of variation (\%) }\end{array}$} \\
\hline & MS [22] & Lpm [23] & N6 [24] & $\mathrm{KC}[25]$ & Mean $^{\star *}$ & \\
\hline \multicolumn{7}{|l|}{ Height (cm) } \\
\hline$C 1: 1.1-2.0$ & 7.8 & 6.2 & 2.3 & 3.2 & $4.9 \mathrm{~b}$ & 18.8 \\
\hline$C 2: 2.1-3.0$ & 7.7 & 6.1 & 3.9 & 3.4 & $5.2 \mathrm{~b}$ & \\
\hline$C 3: 3.1-4.0$ & 8.3 & 7.4 & 5.5 & 5.2 & $6.6 \mathrm{a}$ & \\
\hline Mean** & $7.9 \mathrm{~A}$ & $6.6 \mathrm{~B}$ & $3.9 \mathrm{C}$ & $3.9 \mathrm{C}$ & 5.6 & \\
\hline \multicolumn{7}{|c|}{ Shoot diameter (mm) } \\
\hline$C 1: 1.1-2.0$ & 5.6 & 6.1 & 5.3 & 4.9 & $5.5 \mathrm{~b}$ & 10.4 \\
\hline$C 2: 2.1-3.0$ & 5.7 & 5.7 & 6.0 & 6.1 & $5.9 a b$ & \\
\hline$C 3: 3.1-4.0$ & 6.2 & 6.3 & 6.2 & 6.1 & $6.2 \mathrm{a}$ & \\
\hline Mean & 5.8 & 6.1 & 5.8 & 5.7 & 5.8 & \\
\hline \multicolumn{7}{|l|}{ Number of roots } \\
\hline$C 1: 1.1-2.0$ & 5.7 & 7.2 & $2.5 \mathrm{~b}$ & 4.9 & 5.1 & $11.2^{1}$ \\
\hline$C 2: 2.1-3.0$ & 5.8 & 6.9 & $6.2 \mathrm{a}$ & 4.7 & 5.9 & \\
\hline$C 3: 3.1-4.0$ & 5.3 & 6.8 & $7.2 \mathrm{a}$ & 4.7 & 6.0 & \\
\hline Mean** & $5.6 \mathrm{AB}$ & $7.0 \mathrm{~A}$ & $5.3 \mathrm{~B}$ & $4.8 \mathrm{~B}$ & 5.7 & \\
\hline \multicolumn{7}{|c|}{ Number of shoots } \\
\hline$C 1: 1.1-2.0$ & 0.9 & 0.3 & 0.2 & 0.7 & 0.5 & $27.5^{1}$ \\
\hline$C 2: 2.1-3.0$ & 1.8 & 0.8 & 1.1 & 0.3 & 1.0 & \\
\hline$C 3: 3.1-4.0$ & 1.2 & 0.2 & 0.9 & 0.2 & 0.7 & \\
\hline Mean* & $1.3 \mathrm{~A}$ & $0.4 \mathrm{~B}$ & $0.8 \mathrm{AB}$ & $0.4 \mathrm{~B}$ & 0.7 & \\
\hline
\end{tabular}

The basal MS and 1/2 MS medium free of NAA and BAP were combined with shoots of the three different shoot sizes (table II). A significant increment was observed in the shoot height $(8.9 \mathrm{~cm})$ and diameter $(5.8 \mathrm{~mm})$ in the full strength MS medium. On the other hand, the different explant size classes affected these parameters. Higher diameter values were achieved from shoots of the C3 class $(6.0 \mathrm{~mm})$. However, the $\mathrm{C} 1$ class shoots showed a multiplication rate of 2.0 shoots per explant, significantly higher than the 1.3 and 1.2 shoots per explant observed from the $\mathrm{C} 2$ and $\mathrm{C} 3$ classes, respectively. For the three classes, the root induction was also high in MS culture medium free of growth regulators.

Most of the shoots (63\%) originated from the inoculation of the $\mathrm{C} 1$ class of explants in the multiplication medium did not reach $2 \mathrm{~cm}$ height (table III). The frequency of that kind of shoot was $32 \%$ and $10 \%$ when C2 and C3 class explants, respectively, were used. The height means of the shoots from these three classes were 1.9, 2.5 and $3.6 \mathrm{~cm}$, respectively, with statistically significant differences by t-test $(P<0.05)$. Within the elongation medium, the shoots exhibited approximately $8.5 \mathrm{~cm}$ of height independently of the explant class size (table III). 


\section{Table II.}

Characteristics of pineapple (cv. Perola) plantlets after 5 weeks of in vitro cultivation on full or half-strength Murashige and Skoog (MS) media [22] (means of three replicates).

\begin{tabular}{|c|c|c|c|c|}
\hline \multirow{2}{*}{$\begin{array}{l}\text { Class of shoot } \\
\text { height }(\mathrm{cm})\end{array}$} & \multicolumn{3}{|c|}{ Culture medium } & \multirow{2}{*}{$\begin{array}{c}\text { Coefficient } \\
\text { of variation }(\%\end{array}$} \\
\hline & MS & $1 / 2 \mathrm{MS}$ & Mean* & \\
\hline \multicolumn{5}{|l|}{ Height (cm) } \\
\hline$C 1: 1.1-2.0$ & 8.7 & 5.1 & 6.9 & 8.2 \\
\hline$C 2: 2.1-3.0$ & 8.5 & 6.0 & 7.2 & \\
\hline C3: $3.1-4.0$ & 9.4 & 5.7 & 7.6 & \\
\hline Mean $^{\star *}$ & $8.9 \mathrm{~A}$ & $5.6 \mathrm{~B}$ & 7.2 & \\
\hline \multicolumn{5}{|c|}{ Shoot diameter (mm) } \\
\hline$C 1: 1.1-2.0$ & 5.5 & 4.7 & $5.1 \mathrm{~b}$ & 8.4 \\
\hline C2: $2.1-3.0$ & 5.5 & 5.3 & $5.4 a b$ & \\
\hline C3: $3.1-4.0$ & 6.3 & 5.6 & $6.0 \mathrm{a}$ & \\
\hline Mean* & $5.8 \mathrm{~A}$ & $5.2 \mathrm{~B}$ & 5.5 & \\
\hline \multicolumn{5}{|l|}{ Number of roots } \\
\hline$C 1: 1.1-2.0$ & 7.0 & 6.0 & 6.5 & 12.4 \\
\hline C2: $2.1-3.0$ & 7.7 & 7.3 & 7.5 & \\
\hline C3: $3.1-4.0$ & 6.4 & 8.2 & 7.3 & \\
\hline Mean & 7.0 & 7.2 & 7.1 & \\
\hline \multicolumn{5}{|c|}{ Number of shoots } \\
\hline$C 1: 1.1-2.0$ & 1.6 & 2.2 & $2.0 \mathrm{a}$ & 25.5 \\
\hline$C 2: 2.1-3.0$ & 1.6 & 1.1 & $1.3 \mathrm{~b}$ & \\
\hline C3: $3.1-4.0$ & 1.2 & 1.3 & $1.2 b$ & \\
\hline Mean & 1.5 & 1.6 & 1.5 & \\
\hline
\end{tabular}

Means with the same letter within a same row (capital letter) or a same column (minuscule letter) are not significantly different according to the Student-NewmanKeuls mean separation test ( ${ }^{*}$ significant at $P<0.05$, ${ }^{*}$ significant at $P<0.01$ ).

\subsection{Acclimatization}

Plantlets higher than $7 \mathrm{~cm}$ (class C6) showed a survival rate of $93 \%$ during the acclimatization phase. These values statistically differed from those observed with the classes C4 and C5 (table IV). Classes C5 and C6 also provided better plant development resulting in values of $14.1 \mathrm{~cm}$ and $13.5 \mathrm{~cm}$ of height, respectively, after 13 weeks. Again, C6 class shoots showed higher values of fresh and dry weight in comparison with the shoots originated from the $\mathrm{C} 4$ and C5 size classes (table IV).

The interaction between autoclaving treatment of the substrate and the type of the substrate significantly affected $(\mathrm{P}<0.01)$ the plant height dry and fresh weights (tableV). The highest average values for plant height $(19.1 \mathrm{~cm})$ and shoot dry weight $(4.1 \mathrm{~g})$ were observed in the non-autoclaved mixture of sand and termophilic organic substrate. On the other hand, the combination of the sandy substrate autoclaved once resulted in higher values of root dry weight (3.6 g). The survival rate of acclimatized plantlets was $100 \%$ (data not shown).

\section{Discussion}

\subsection{Induction}

The results of the present work revealed that the use of MS culture medium supplemented with NAA $(2 \mu \mathrm{M})$ and BAP $(4 \mu \mathrm{M})$ enhanced the proliferation of neoformed buds. The same combination was employed in the induction of nodular cultures [13]. However, the shoot proliferation from buds of the crown was obtained with the combination of NAA and kinetin [9], or IAA (indole-3-acetic acid) and BAP in the establishment phase [12] or BAP alone [18].

\subsection{Multiplication}

In the present work, the best multiplication rate was 13.5 shoots per explant for cv. Pérola in the same MS culture medium employed in the induction phase. In the cv. Smooth Cayenne, 4.2 shoots per explant were observed in basal culture medium MS supplemented with NAA and BAP [6]. A proliferation rate of 6.0 shoots per explant for cv. Smooth Cayenne was obtained as a result of the addition of zeatin $(9.1 \mu \mathrm{M})$ to the MS culture medium [7]. The best proliferation rate was observed in the MS medium supplemented with $4.6 \mu \mathrm{M}$ of kinetin and $5.4 \mu \mathrm{M}$ of NAA [18]. The MS culture medium plus IAA $(1 \mu \mathrm{M})$ and BAP $(10 \mu \mathrm{M})$ produced 2 to 3 shoots per explant after 6 weeks in culture [8]. It was observed that the proliferation rate was dependent on the genotype and the levels of BAP in the culture medium [12]. In fact, the proliferation rate obtained in the present work was higher than other average rates so far reported. 
Table III.

Number and frequency of micropropagated pineapple shoots (cv. Perola) after 5 weeks of in vitro cultivation on two different culture media.

a) on a multiplication culture medium: Murashige and Skoog medium + NAA $(2 \mu \mathrm{M})+$ BAP $(4 \mu \mathrm{M})$

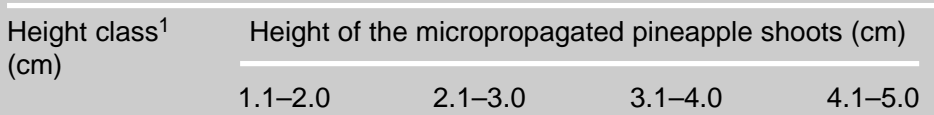

$\begin{array}{crrrr}\text { Shoot number } & & & & \\ C 1 & 20 & 12 & 0 & 0 \\ \text { C2 } & 12 & 15 & 11 & 0 \\ \text { C3 } & 3 & 5 & 8 & 12\end{array}$

Frequency (\%)

$\begin{array}{lllll}C 1 & 63 & 37 & - & - \\ C 2 & 32 & 39 & 29 & - \\ C 3 & 10 & 18 & 29 & 43\end{array}$

b) on an elongation culture medium: Murashige and Skoog medium

\begin{tabular}{|c|c|c|c|c|c|c|c|c|}
\hline \multirow{2}{*}{$\begin{array}{l}\text { Height class }{ }^{1} \\
(\mathrm{~cm})\end{array}$} & \multicolumn{8}{|c|}{ Height of the micropropagated pineapple shoots $(\mathrm{cm})$} \\
\hline & $4.1-5.0$ & $5.1-6.0$ & $6.1-7.0$ & $7.1-8.0$ & $8.1-9.0$ & $9.1-10.0$ & $10.1-11.0$ & $11.1-12.0$ \\
\hline \multicolumn{9}{|l|}{ Shoot number } \\
\hline$C 1$ & 1 & 0 & 0 & 6 & 5 & 7 & 2 & 0 \\
\hline$C 2$ & 0 & 2 & 2 & 6 & 2 & 8 & 3 & 0 \\
\hline C3 & 0 & 0 & 0 & 1 & 10 & 5 & 6 & 2 \\
\hline \multicolumn{9}{|l|}{ Frequency (\%) } \\
\hline$C 1$ & 5 & - & - & 29 & 24 & 33 & 10 & - \\
\hline$C 2$ & - & 9 & 9 & 26 & 9 & 35 & 12 & - \\
\hline C3 & - & - & - & 4 & 42 & 21 & 25 & 8 \\
\hline
\end{tabular}

${ }^{1}$ Height classes of the plantlets inoculated for multiplication or elongation: $C 1:(1.1-2.0) \mathrm{cm}$; C2: $(2.1-3.0) \mathrm{cm}$; $C 3:(3.1-4.0) \mathrm{cm}$.

The differences observed in the in vitro pineapple proliferation rate can be attributed to (i) the basal medium culture composition, (ii) the plant growth regulator type and concentration, (iii) the number and interval length of sub-cultures, (iv) the multiplication system, and (v) the genotype. However, the highest plantlet production is not always correlated with the best propagation system in terms of genotype quality and ex vitro performance [19]. Even considering a linear increase in the multiplication rate up to the eleventh subculture [6], the results of the present work showed that this increase occurred up to the sixth subculture.
It has been suggested that some malformation of plantlets was common in the micropropagation of some herbaceous species, mainly in medium with high levels of citokinins and humidity [28]. The use of anti-hyperhydric agents [29], culture medium free of cytokinins, low temperatures, and absence of light [30] could prevent these effects. In the present work, we were able to reduce the vitrification in culture media free of growth regulators, which was noticed after the sixth subculture in the multiplication medium. No other type of malformation was observed. The vitrification generally seems to be the most intense in culture liquid medium [31] or under low agar levels 


\begin{tabular}{|c|c|c|c|c|}
\hline \multirow{2}{*}{$\begin{array}{l}\text { Height class of plantlets } \\
\text { before acclimatization } \\
(\mathrm{cm})\end{array}$} & \multicolumn{4}{|c|}{ Plant after acclimatization } \\
\hline & $\begin{array}{l}\text { Height ** } \\
\text { (cm) }\end{array}$ & $\begin{array}{l}\text { Fresh weight* } \\
\text { (g) }\end{array}$ & $\begin{array}{l}\text { Dry weight }{ }^{* *} \\
\text { (g) }\end{array}$ & $\begin{array}{c}\text { Plant survival** } \\
(\%)\end{array}$ \\
\hline C6: 7.1-9.0 & $14.1 \mathrm{a}$ & $15.9 \mathrm{a}$ & $1.9 \mathrm{a}$ & 93.8 a \\
\hline C5: 7.1-9.0 & $13.5 \mathrm{a}$ & $12.8 \mathrm{~b}$ & $1.5 \mathrm{~b}$ & $81.3 \mathrm{~b}$ \\
\hline C4: $7.1-9.0$ & $11.3 \mathrm{~b}$ & $10.8 \mathrm{c}$ & $1.3 \mathrm{~b}$ & $79.2 \mathrm{~b}$ \\
\hline Mean & 13.0 & 13.2 & 1.6 & 85.0 \\
\hline Coefficient of variation (\%) & 8.5 & 7.1 & 9.1 & 7.3 \\
\hline
\end{tabular}

Means with the same letter within a same column are not significantly different according to the Student-Newman-Keuls mean separation test $\left({ }^{*}\right.$ significant at $P<0.05$, ${ }^{* *}$ significant at $\left.P<0.01\right)$.

[29]. When caused by auxins, this event can be attributed to the accumulation of ethylene in the culture [31]. However, these alterations are generally epigenetic [32, 33]

Several authors have developed other methods of in vitro culture of $\mathrm{A}$. comosus resulting in high rates of multiplication. Kiss et al. obtained rates of 13 and 15 plantlets per nodal segment, in a N6 supplemented with BAP $(20 \mu \mathrm{M})$ and kinetin $(25 \mu \mathrm{M})$ culture medium [10]. Teng achieved a multiplication rate of 51.5 shoots per $0.4 \mathrm{~g}$ of nodular explant, from the induction of nodules

\section{Table V.}

Characteristics, after 13 weeks of cultivation, of pineapple (cv. Pérola) plants originated from elongation and rooting stage on in vitro culture medium, then transfered on two different substrates subjected to three autoclaving treatments at $121^{\circ} \mathrm{C}$ and $1 \mathrm{~atm}$ (means of four replicates).

\begin{tabular}{|c|c|c|c|c|}
\hline Substrate & $\begin{array}{l}\text { Without } \\
\text { autoclave }\end{array}$ & $\begin{array}{l}\text { One passage } \\
\text { at } 121^{\circ} \mathrm{C} \\
\text { during } 30 \mathrm{~min}\end{array}$ & $\begin{array}{l}\text { Two passages } \\
\text { at } 121^{\circ} \mathrm{C} \text { during } 30 \mathrm{~min} \\
\text { with a } 24 \mathrm{~h} \text { interval }\end{array}$ & $\begin{array}{c}\text { Coefficient } \\
\text { of variation (\%) }\end{array}$ \\
\hline \multicolumn{5}{|l|}{ Height (cm) } \\
\hline Sand & $15.0 \mathrm{c}$ & $15.7 \mathrm{bc}$ & $16.0 \mathrm{bc}$ & 4.3 \\
\hline Sand + compound termophilic & $19.1 \mathrm{a}$ & $17.0 \mathrm{~b}$ & $17.0 \mathrm{~b}$ & \\
\hline \multicolumn{5}{|l|}{ Plant dry weight (g) } \\
\hline Sand & $2.3 \mathrm{c}$ & $3.0 \mathrm{~b}$ & $3.2 \mathrm{~b}$ & 9.5 \\
\hline Sand + compound termophilic & $4.1 \mathrm{a}$ & $3.5 \mathrm{~b}$ & $3.3 b$ & \\
\hline \multicolumn{5}{|l|}{ Root dry weight (g) } \\
\hline Sand & $2.1 \mathrm{~b}$ & $3.6 \mathrm{a}$ & $3.1 \mathrm{a}$ & 18.5 \\
\hline Sand + compound termophilic & $2.1 \mathrm{~b}$ & $1.9 \mathrm{~b}$ & $2.0 \mathrm{~b}$ & \\
\hline
\end{tabular}

Means with the same letter and corresponding to a same characteristic (interaction of the two factors) are not significantly different according to the Student-Newman-Keuls mean separation test at $P<0.01$. 
in a MS supplemented with NAA $(0.54 \mu \mathrm{M})$ and $\operatorname{BAP}(0.44 \mu \mathrm{M})$ culture medium [13]. On the other hand, Mayak et al. observed enhancement in the in vitro growth and development of $\mathrm{cv}$. Smooth Cayenne when the culture medium was enriched with $\mathrm{CO}_{2}$ at $3 \times 10^{3} \mu \mathrm{L} \times \mathrm{L}^{-1}$ [18]. Considering that the pineapple has a crassulacean acid metabolism, an increase in the dry matter of the plantlets was observed when the $\mathrm{CO}_{2}$ level was raised from 330 to $730 \mu \mathrm{M}$ [34].

When compared to other in vitro regenerative systems based on direct organogenesis, the results of the present work showed a higher multiplication rate. In consequence, it is important to define and to establish every step of the regenerative protocol so that it can be enhanced in terms of proliferation rate, subculture intervals, low risks of genetic variations and costs, for utilizing this technology in large-scale commercial production and automated systems [35, 36]

The frequencies of shoot smaller than $2 \mathrm{~cm}$ in height obtained for the C1, C2 and C3 classes were $63 \%, 32 \%$, and $10 \%$, respectively. Although the shoots with that height could be transferred to the elongation medium, they may be returned to the multiplication medium as suggested in figure 3 , because they can be used as explants. From the total, one third of the shoots could be returned to the multiplication medium and two thirds should be transferred to the elongation medium. However, since the explant height did not affect the shoot height in the elongation medium, the system will be more efficient if $\mathrm{C} 1$ class explants are used in the multiplication medium because it regenerates a higher frequency of $\mathrm{C} 1$ class explants at higher a proliferation rate, which is suitable to maintain the system functioning.

\subsection{Elongation and rooting}

In the present work, the basal MS medium free of plant growth regulators revealed an increment in the shoot height and diameter values. When a plantlet from the (1 to 2) $\mathrm{cm}$ C1 class was inoculated, the increment in height was about 7.2 times during the elongation stage. The data of the present work confirmed the hypothesis that the basal

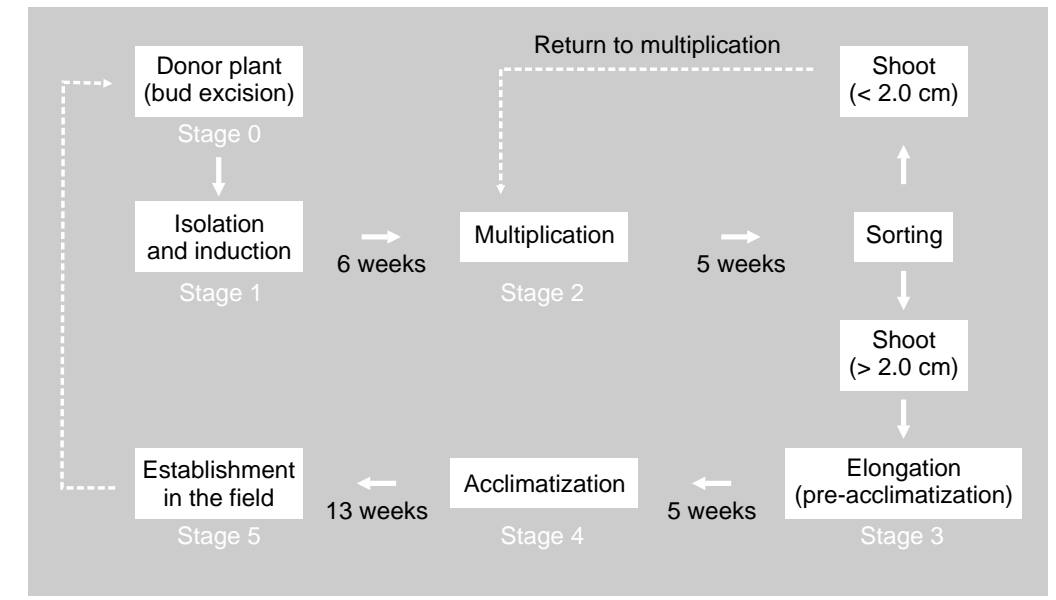

culture medium free of growth regulators promotes the shoot elongation. The best general aspect of the shoots and the absence of plantlets with hyperhydricity could be foreseen as indicative of good acclimatization and field establishment stages. Some negative aspects like vitrification and precocious bud burst have been associated with the growth regulator used in the multiplication stage [20]. Therefore, it is important to maintain these plantlets in the culture medium free of growth regulator as a step of pre-acclimatization.

The basal saline composition is an important factor optimizing the in vitro responses [37]. The change of the MS basal medium to the N6 basal medium was necessary to improve the pineapple shoot induction rate [10]. Among the different saline formulas tested for the pineapple, the MS one has been the most utilized [6-8, 10-12, 17]. The half-strength MS [13] and the MT [38] media [9] has also been employed.

In the present work, it was also observed that the basal culture medium free of growth regulators was satisfactory to induce the plantlet rooting. Additional small shoot growth and the induction of plantlet rooting were observed after the transference to a culture medium free of growth regulators $[10,12,15]$. On the other hand, Teng used MT basal medium plus NAA $(5.38 \mu \mathrm{M})$ and malt extracts to induce rooting [13]; Hirimburegama and Wijesinghe only added NAA $\left(10^{-7} \mu \mathrm{M}\right)$ to basal medium to get full

\section{Figure 3.}

Process proposed for pineapple mass clonal micropropagation. 
plantlets [8], and Teng obtained better rooting when higher levels of NAA than BAP were used [13].

\subsection{Acclimatization}

In the present work, some factors were evaluated to improve the acclimatization stage for getting high plantlet survival rates. First, a survival rate of $100 \%$ was possible when the in vitro derived plantlets were higher than $7.0 \mathrm{~cm}$, independent of the substrate. Second, better acclimatization occurring during the spring-summer period was preferred, because of a better survival rates (>90\%) as compared to the autumn-winter time $(<90 \%$, data not shown). Therefore, by decreasing the stress conditions during heterotrophic adaptation, it is possible to reached high survival rates [39]. In this regard, an excessive water loss by transpiration and an impaired photosynthetic apparatus are the two major problems [40].

\section{Proposal for an improved protocol}

The results obtained in the present work finally suggest an improved in vitro regenerative protocol for pineapple, with the following procedures (figure 3):

1) stage zero: the selection and maintenance of mother plants in greenhouse conditions;

2) stage 1: bud isolation on test tubes over bridge filter paper in MS liquid culture medium supplemented with NAA $(2 \mu \mathrm{M})$ and BAP $(4 \mu \mathrm{M})$, for 6 weeks;

3) stage 2: multiple bud induction in $500 \mathrm{~mL}$ flasks containing $30 \mathrm{~mL}$ of the same medium composition referred to in stage 1 , with 5 weeks subculture intervals;

4) stage 3: sorting of the shoots higher than $2 \mathrm{~cm}$ and subcultures in an elongation MS medium free of growth regulators. Shoots with a size inferior to $2 \mathrm{~cm}$ should return to the multiplication phase (stage 2);

5) stage 4: acclimatization of the plantlets higher than $7.0 \mathrm{~cm}$, after 5 week in stage 3;

6) stage 5: transference of the plants with height between 15 and $20 \mathrm{~cm}$ to the field.

\section{Final prospects}

In horticulture, the tissue techniques can be used for the production of specific pathogenfree plants, germplasm storage, mass clonal propagation or plant changes [41]. In this respect, the pineapple is a species where the application of these techniques may present several advantages.

The results of the present work indicated that starting from a single bud and considering a 45 day subculture interval and an average multiplication rate of 10 shoots per bud, it is possible to obtain one million in vitro plantlets after 9 months. Considering an average of $7 \%$ losses during the acclimatization phase and an interval of 3 months to allow the growth of the plantlets before the field establishment, it is possible to produce 930,000 plantlets in 1 year.

The technical advances in the establishment and improvement of the protocol used in pineapple micropropagation revealed by this work indicated a reduction in the final cost of plantlets and the production of fusariosis-free plantlets in a short time period and controlled conditions.

\section{Acknowledgements}

This work was supported by grants from the Brazilian Research Council (CNPq).

\section{References}

[1] Cabral J.R.S., Matos A.P., Cunha G.A.P., Selection of pineapple cultivars resistant to fusariose, Acta Hortic. 334 (1993) 53-58.

[2] Cabral J.R.S., Matos A.P., Pineapple breeding for resistance to fusariosis in Brazil, Rev. Fac. Agron. Maracay 21 (1995) 137-145.

[3] Leal F, Coppens d'Eckenbrugge G., Pineapple, in: Janick J., Moore J.N. (Eds.), Fruit Breeding - Tree and Tropical Fruits, John Wiley, New York, 1996, pp. 515-557.

[4] Aghion D., Beauchesne G., Utilisation de la technique de culture stérile d'organes pour obtenir des clones d'ananas, Fruits 15 (1960) 464-466. 
[5] Rangan T.S., Pineapple, In: Ammirato P.V., Evans D.A., Sharp W.R., Yamada Y. (Eds), Handbook of plant cell culture, Macmillan Publishing Co, New York, 1984, pp. 373-82.

[6] Dewald M.G., Moore G.A., Sherman W.B. Evans M.H., Production of pineapple in vitro, Plant Cell Rep. 7 (1988) 535-537.

[7] Fitchet M., Clonal propagation of Queen and Smooth Cayenne pineapples, Acta Hortic. 275 (1990) 261-266.

[8] Hirimburegama K., Wijesinghe L.P.J., In vitro growth of Ananas comosus L. Merr. (pineapple) shoot apices on different media, Acta Hortic. 319 (1992) 203-208.

[9] Fitchet-Purnell M., Maximum utilization of pineapple crowns for micropropagation, Acta Hortic. 334 (1993) 325-330.

[10] Kiss E., Kiss J., Gyulai G., Heszky L.E., A novel method for rapid micropropagation of pineapple, HortSciences 30 (1) (1995) 127-129.

[11] Daquinta M., Benega R., Brief review of tissue culture in pineapple, Pineapple News 3 (1) (1997) 7-9.

[12] Almeida W.A.B. de, Matos A.P. de, Souza A da S., Effects of benzylaminopurine (BAP) on in vitro proliferation of pineapple (Ananas comosus (L.) Merr.), Acta Hortic. 425 (1997) 235-242.

[13] Teng W.L., An alternative propagation method of Ananas through nodule culture, Plant Cell Rep. 16 (1997) 454-457.

[14] Guerra M.P., Dal Vesco L.L., Pescador R., Schuelter A.R., Nodari R.O., Establishment of a regenerative protocol for the pineapple micropropagation, Pesq. Agropecu. Bras. 34 (9) (1999) 1557-1563.

[15] Wakasa K., Pineapple (Ananas comosus L. Merr.), In: Bajaj Y.P.S. (Ed), Biotechnology in Agriculture and Forestry - Trees II, SpringerVerlag, Berlin, Germany, 1989, pp.13-29.

[16] Fitchet M., Organogenesis in callus cultures of pineapples (Ananas comosus (L.) Merr., Acta Hortic. 275 (1990) 267-274.

[17] Benega R., Isidrón M., Arias E., Cisneros A. Companioni L., Martínez J., Borroto C.G., Plant regeneration from pineapple (Ananas comosus L. Merr.) ovules, Acta Hortic. 425 (1997) 247-250.

[18] Mayak S., Tirosh T., Ilan A., Duvdevani A. Khayat E., Growth and development of pineapple (Ananas comosus L.) plantlets cultured in vitro at enriched and ambient $\mathrm{CO}_{2}$ environments, Acta Hortic. 461 (1998) 225-229.

[19] Debergh P.C., Read P.E., Micropropagation, In: Debergh P.C., Zimmerman R.H. (Eds.), Micropropagation - Technology and application, Kluwer Academic Pu., Dordrecht, Netherlands, 1991, pp. 1-13.
[20] George E.F., Plant propagation by tissue culture, Exegetics, Edington, UK, Part 1, 1993, $574 \mathrm{p}$.

[21] Krikorian A.D., Hormones in tissue culture and micropropagation, in: Davies P.J. (Ed.), Plant hormones, Kluwer Academic Pu, Dordrecht, Netherlands, 1995, pp. 774-796.

[22] Murashige T., Skoog F., A revised medium for rapid growth and bioassays with tobacco tissue cultures, Physiol. Plantarum 15 (1962) 473-497.

[23] von Arnold S., Eriksson T., In vitro studies of adventitious shoot formation in Pinus contorta, Can. J. Bot. 59 (1981) 870-874.

[24] Chu C.C., The N6 medium and its applications to anther culture of cereal crops, In: Proceedings symposium on plant tissue culture, Pitman Advanced Pu. Program, Boston, USA, 1981, pp. 43-50.

[25] Knudson L., A new nutrient solution for germination of orchid seed, Am. Orchid Soc. Bull. 14 (1946) 214-217.

[26] Steel R.G.D., Torrie J.H., Principles and procedures of statistics -A biometrical approach, Mcgraw-Hill Book Co, New York, USA, 1980, $633 \mathrm{p}$.

[27] Compton M., Statistical methods suitable for the analysis of plant tissue culture data, Plant Cell Tiss. Org. 37 (1994) 217-242.

[28] Gaspar T., The concept of cancer in in vitro plant cultures and the implication of habituation to hormones and hyperhydricity, Plant Tiss. Cult. Biotechnol. 1 (3) (1995) 126-136.

[29] Marga F., Vebret L., Morvan H., Agar fractions could protect apple shoots cultured in liquid media against hyperhydricity, Plant Cell Tiss. Org. 49 (1997) 1-5.

[30] Nobre J., In vitro cloning and micropropagation of Lavandula stoechas from field-grown plants, Plant Cell Tiss. Org. 46 (1996) 151-155.

[31] Ziv M., Vitrification, morphological and physiological disorders of in vitro plants, In: Debergh P.C., Zimmerman R.H. (Eds), Micropropagation - Technology and application, Kluwer Academic Pu, Dordrecht, Netherlands, 1991, pp. 45-69.

[32] Larkin P.J., Scowcroft W.R., Somaclonal variation - A novel source of variability from cell cultures for plant improvement, Theor. Appl. Genet. 60 (1981) 197-214.

[33] Peschke V.M., Phillips R.L., Genetic implications of somaclonal variation in plants, Adv. Genet. 30 (1992) 41-75.

[34] Zhu J., Bartholomew D.P., Goldstein G., Effect of elevated carbon dioxide on the growth and physiological responses of pineapple, a species with crassulacean acid metabolism, J. Am. Soc. Hortic. Sci. 122 (2) (1997) 233-237. 
[35] Vasil I.K., Automation of plant propagation, Plant Cell Tiss. Org. 39 (1994) 105-108.

[36] George E.F., Plant propagation by tissue culture, Exegetics, Edington, UK, Part 2, 1996, $699 \mathrm{p}$.,

[37] Preece J.E., Can nutrient salts partially substitute for plant growth regulators?, Plant Tiss. Cult. Biotechnol. 1 (1) (1995) 26-36.

[38] Murashige T., Tucker D.P.H., Growth factor requirements of Citrus tissue culture, In: Chapman H.D. (Ed.), Proc. 1st Int. Citrus Symp. V.3., Univ. Calif. Riverside, Riverside, Ca, USA, 1969, pp. 1115-1161.
[39] Preece J.E., Sutter E.G., Acclimatization of micropropagated plants to the greenhouse and field, In: Debergh P.C., Zimmerman R.H. (Eds), Micropropagation - Technology and application, Kluwer Academic Pu, Dordrecht, Netherlands, 1991, pp. 71-93.

[40] Van Huylenbroeck J.M., Debergh P.C., Physiological aspects in acclimatization of micropropagated plantlets, Plant Tiss. Cult. Biotechnol. 2 (3) (1996) 136-141.

[41] Thorpe T.A., Harry I.S., Application of tissue culture to horticulture, Acta Hortic. 447 (1997), 39-49.

\section{Mejoramiento de un protocolo de micropropagación de piña pela manipulación del tamaño del explante y la composición del medio.}

Resumen - Introducción. Aunque numerosos protocolos de micropropagación de piña están siendo trabajados en todo el mundo, ganancias significativas suelen ser alcanzadas cuando los estadios del cultivo in vitro son mejor establecidos. Teniendo en cuenta este hecho, varios ensayos fueron establecidos en protocolos considerando diferentes estadios, conduciendolos para producción masal con explantes de alta calidad. Material y métodos. Yemas axilares fueron cultivadas en medio MS basal líquido, suplementado con NAA ( $2 \mu \mathrm{M})$ y BAP $(4 \mu \mathrm{M})$. Los brotes fueron clasificados en tres clases en cuanto a su tamaño: C1 $(1,1-2,0 \mathrm{~cm})$, C2 $(2,1-3,0 \mathrm{~cm})$ y C3 $(3,1-4,0 \mathrm{~cm})$ y fueron empleados en ensayos adicionales. En el primero, estos brotes fueron cultivados en frascos conteniendo el mismo medio de cultivo basal con o sin hormonas. En el segundo, fueron experimentadas cuatro formulaciones de medio distintos: MS, LPm, N6 y Knudson sin hormonas. En el tercer ensayo, los medios de cultivo MS y $1 / 2$ MS fueron comparados en cuanto a promover el desarrollo de los brotes y de las raíces. Resultados. Los explantes C1 cultivados en medio MS suplementados con de NAA y BAP presentaron alta tasa de multiplicación (13,5 brotes). Brotes de clase C3 cultivados en medio MS sin hormonas presentaron brotes de talla alta $(7,7 \mathrm{~cm})$ y sin vitrificación. El medio MS completo en cuando comparado al $1 / 2 \mathrm{MS}$ o a las otras tres formulaciones de medio de cultivo, han presentado una significativa ganancia en el desarrollo de los brotes y mejores características generales. En cuanto a la aclimatación, las plántulas oriundas del cultivo in vitro en que los brotes eran de más de $7 \mathrm{~cm}$, presentaron tasas de supervivencia alta $(93,8 \%)$, de peso fresco y materia seca. Conclusión. El empleo de este protocolo, a partir de una sola yema, considerando el intervalo de 45 días de subcultivo y una tasa media de multiplicación de 10 brotos/yema, es posible obtener uno millón de plantas in vitro después de nueve meses.

Brasil / Ananas comosus / propagación de plantas / micropropagación / experimentación in vitro / medio de cultivo / trasplante / establecimiento de plantas 